\title{
Not Just Business as Usual in the EU: A Comprehensive Analysis of Immigration and Tax Issues Related to Business Trips in 17 Schengen Countries
}

\author{
Marco Mazzeschi ${ }^{1,2}$ \& Clayton E. Cartwright $\mathrm{Jr}^{3}$ \\ ${ }^{1}$ Milan Bar Association, Italy \\ ${ }^{2}$ Taipei Bar Association, Taiwan \\ ${ }^{3}$ The Cartwright Law Firm, LLC, in Columbus, Georgia \\ Correspondence: Marco Mazzeschi, an attorney at law, Milan Bar Association, Italy. Foreign practicing lawyer, \\ Taipei Bar Association, Taiwan.
}

Received: January 8, 2018

Accepted: February 1, 2018

Online Published: February 8, 2018

doi:10.5430/ijba.v9n2p46

URL: https://doi.org/10.5430/ijba.v9n2p46

\begin{abstract}
This article undertakes a comparative analysis of doing business in the European Union's Schengen Bloc vis-à-vis working in the Schengen Bloc. Through a critical review of what may constitute business activities vs. work in all 17 Schengen member states, the article establishes how international companies can minimize unintentional exposure to immigration noncompliance as well as possible tax liabilities. As the article observes, there is a general absence of a standard EU legal definition of 'work' vs. 'business activities' that international companies can apply when sending employees for business purposes to the Schengen Bloc. In the absence of specific criteria, the article outlines what characterizes business activities in 17 Schengen countries and then several international standards, which concerned parties can use a reference point. By examining various sources including EU, OECD and ILO frameworks, the article's research indicates general terms of reference in distinguishing business activities from work, and how that distinction confers the need for a business visa or a work permit in the European Union's Schengen Bloc.
\end{abstract}

Keywords: business trips eu, work permits eu, doing business in the schengen bloc, business travel schengen bloc

\section{Introduction}

Globalization requires companies to increasingly move their workers around the world and such moves often happen quickly. The most practical and common way to send workers abroad for a short-term assignment is for the workers to travel on 'busines's. In many countries, business visitors are exempted from obtaining a visa. For those countries in which a visa is required, obtaining a business visa is notably easier and quicker than applying for a work visa. There are however, many areas of potential risk when employees travel outside of their home country on business, which could expose the worker and both sending and host company to sanctions for non -compliance with employment, social security and immigration laws. Additionally, there are possible tax risks deriving from an unintended taxable presence created in the host country and the recognition of a permanent establishment with the consequent tax liability for the foreign company. This article outlines the possible criteria which could be considered in the absence of an internationally recognized frame of reference that establishes which activities can be legitimately considered as "business" and which activities could be considered, alternately, as 'work.' In the case of the later, there is often the unintended consequence of creating a permanent establishment in the host country and associated exposure to tax liabilities.

\section{What Is "Business"?}

The Schengen Visa Code and Schengen Acquis (Council Decision, 1999) do not contain a definition of what must be considered 'business' activity that can be carried out without obtaining a work permit. The Schengen Handbook for the processing of visa applications and the modification of issued visas (COMMISSION IMPLEMENTING DECISION C, 2011) contains only a non-exhaustive list of supporting documents for business trips and underlines that for persons travelling for the purpose of carrying out paid activity "The applicant must provide a work permit or 
any similar document as provided by the national legislation of the Member State where a paid activity is to be carried out, if applicable".

\subsection{Business Definition in the Schengen Area}

None of the Schengen Member State legislation contains, however a clear and specific definition of what can be considered "business". Below is a summary table of 17 Schengen countries' regulations concerning business visitors.

\begin{tabular}{|c|c|c|}
\hline $\begin{array}{l}\text { Country } \\
\text { (Note 1) }\end{array}$ & Relevant Legislation & $\begin{array}{l}\text { Short Term Business Activity Definition (for } T C N s \text { that do not } \\
\text { require a Work Permit) }\end{array}$ \\
\hline \multirow[t]{5}{*}{ Austria } & Aliens Employment Act & Sec 18; Subsec 2AEA: \\
\hline & & $\begin{array}{l}\text { Short term work (less than one week) that cannot be carried } \\
\text { out by Austrian employees } \\
\text { Participation in business meetings, conferences and trade } \\
\text { shows }\end{array}$ \\
\hline & Aliens Police Act & None \\
\hline & Immigration Act & None \\
\hline & $\begin{array}{l}\text { Austrian Act Against Wage } \\
\text { and Social Dumping }\end{array}$ & $\begin{array}{l}\text { Business and team meetings without direct commercial or } \\
\text { financial value } \\
\text { Fact finding meetings } \\
\text { - } \quad \text { Contract negotiations }\end{array}$ \\
\hline Belgium & $\begin{array}{l}\text { Work Permit Royal Decree of } \\
9 \text { June } 1999\end{array}$ & $\begin{array}{l}\text { - } \quad \text { Meetings in Closed Circle" (max. } 20 \text { consecutive calendar days } \\
\text { - } \quad \text { Scientific conferences } \\
\text { - } \quad \text { Initial assembly/first installation of products (max. } 8 \text { days } \\
\text { overall) } \\
\text { - Urgent maintenance/repair works (max. } 5 \text { days per month) } \\
\text { - Training in group company (max. } 3 \text { months) } \\
\text { - Testing prototypes of vehicles, or other prototypes (max. } 4 \text { weeks } \\
\text { per calendar year per employee) }\end{array}$ \\
\hline Denmark & & $\begin{array}{l}\text { - Actual commercial relationship between the company applicant } \\
\text { belongs to and the host company in Denmark for business visa } \\
\text { (max. } 90 \text { days) } \\
\text { - Teaching or attending a course } \\
\text { - } \text { Participating in meetings } \\
\text { - Negotiations } \\
\text { - } \text { Briefings and training } \\
\text { A work permit required if the point of the visit is to create a } \\
\text { company in any way }\end{array}$ \\
\hline France & November $2016 \mathrm{Job}$ & - $\quad$ Max. 90 days \\
\hline & Categories & $\begin{array}{ll}\text { - } & \text { Sport, cultural, artistic and scientific events } \\
\text { - } & \text { Conferences, seminars and trade shows } \\
\text { - } & \text { Filming and broadcasting activities } \\
\text { - } & \text { Modelling } \\
\text { - } & \text { Audits } \\
\text { - } & \text { Teaching activities provided on an occasional basis by invited } \\
\text { - } & \text { professors } \\
& \text { Short business meetings which do not directly add value to a } \\
& \text { service or product. }\end{array}$ \\
\hline Germany & & $\begin{array}{l}\text { - } \text { Lives and works outside Germany } \\
\text { - } \text { Attending meetings and briefings } \\
\text { - } \text { Trainings at an affiliated company of his/her employer (in-house } \\
\text { - } \quad \text { Negotiation } \\
\text { - } \quad \text { Buying goods for export }\end{array}$ \\
\hline
\end{tabular}


- Installation of machinery or software

- Additional categories exist for sportspersons, journalists, artists, etc.

$\begin{array}{ll}\text { Greece } & \text { Law 4251/2014 } \\ & \text { CPD (Common Presidential } \\ & \text { Decision) 24235/2014 } \\ & \text { (B'2181) }\end{array}$

Hungary

Italy Interministerial Decree $n$. $850 / 2011$

Luxembourg Law of 29 August 2008

$\begin{array}{ll}\text { Malta } & \text { Immigration Act, Chapter } 217 \\ \text { of the Laws of Malta } \\ \text { Legal Notice } 430 \text { of } 2002\end{array}$

Netherlands Article 1 Executive Decree Act on Work by foreigners (Besluit uitvoering Wet arbeid vreemdelingen)
- Meetings, conferences, seminars and similar business-related activities and events

- No definition of business activity

- All legal relationships should be considered work if it relates to employment of a person against remuneration

- Conducting contacts and negotiations

- Training

- Verifying the use and functioning of capital goods purchased or sold under commercial and industrial cooperation agreements

- Meetings with professional partners

- Development of professional contacts

- Conducting contacts and negotiations

- Attend fairs and exhibitions,

- Meetings of boards of directors and general assembly of companies

- All foreign nationals who want to work in Malta need an employment licence

- Posted workers do not need an employment licence, but the undertaking in Malta to which the employee is posted must notify the Department of Industrial and Employment Relations of the posting

- In the case of a third country national employee employed by a posting undertaking established in an EU/EEA country, a working licence is not required in Malta if the posted worker already has a working licence issued in the country where the posting undertaking is established

The visitor must have his residence outside the Netherlands and carry out activities that are strictly limited to:

- Assembling or repairing hardware, delivered by his home country employer (max. 12 weeks in 36 weeks; single entry)

- Installing, implementing or adjusting software, delivered by his home country employer ( $\max .12$ weeks in 36 weeks; single entry)

- Preparing, and/or setting up, and/or breaking down an exhibition or stand on behalf of a foreign client (max. 12 weeks in 36 weeks; single entry)

- $\quad$ Attending business meetings or closing agreements (max. 13 weeks in 52 weeks; multiple entry)

- Making a news report or a documentary on behalf of an agency abroad (max. 6 weeks in 13 weeks; single entry)

- Working in the household of tourists (max. 6 weeks in 13 weeks; single entry)

- Participating in a match as an athlete or working as the athlete's personal assistant (max. 6 weeks in 13 weeks; single entry)

- Performing as an artist or musician or working as their personal assistant (max. 6 weeks in 13 weeks; single entry)

- Working as a visual artist, conservator or restorer (max. 6 weeks in 13 weeks; single entry)

- Controlling or inspecting of goods, foodstuff or animal feed, manufactured in the Netherlands, on behalf of a foreign authority 
in view of importing those items (max. 12 weeks in 36 weeks; single entry)

- Controlling or inspecting of goods, foodstuff or animal feed, manufactured in the Netherlands, on behalf of a foreign authority, for the purpose of issuing a certificate in view of importing those items (max. 12 weeks in 36 weeks; single entry)

- $\quad$ Receiving training or instructions (not: conducting or delivering) (max. 12 weeks in 36 weeks; single entry);

- Certain categories international transport staff, seafarers, foreign correspondents, military, NAVO and other NGO staff and scholars

\section{Poland}

\section{Portugal Law No. 23/2007, of 4 July}

Romania *No specific legislation

Spain Section 8 of the Royal decree $577 / 2011$
- Members of management boards (boards of directors) of entities registered in Poland (max. six months in any calendar year)

- Employees seconded to Poland for the purpose of assembling, preserving or repairing machines, devices or other equipment produced by a foreign employer (max. 3 months during a calendar year)

- Employees seconded to a Polish subsidiary or branch office by a foreign employer on an intra-corporate transfer (max. 30 days within a calendar year.)

- Employees seconded to Poland for other purposes than ICT (max. 30 days within every 6 months)

- Certain categories of foreign language teachers;

- Certain categories of accredited foreign media correspondents

- Attending meetings

- Business prospection

- Training

- Contracts negotiations

- The emplacement, commissioning or verification of the use and operation of the goods acquired or sold under commercial and industrial cooperation agreement

- Training of the local employees in such respect

- Attending meetings, discussions, interviews, conferences or seminars

- Attending or participate in a conference while not exceeding the business area or exhibition

- Attending "fact-finding" meetings

- Attending fairs and congresses 


\section{Sweden}

Switzerland Examples defined by the Swiss State Secretariat for Migration to differentiate stays with and without categorisation as activity of gainful employment according to Art. 11 Abs. 2 FNA (Foreign Nationals Act). Gainful employment itself is defined in Art. 1a and Art. 2 of the Regulation on Admission, Residence and Employment as well as in Fig. 4.1.1. of the Explanatory Directive to the FNA, issued by the State Secretariat for Migration.
- $\quad$ Specialists within an international group who work in Sweden for the group (max. one year cumulative)

- Employees who participate in practical experience, internal training or other skills development at a company in an international group for (max. three months over one year)

- Training, testing, preparation or completion of deliveries or similar activities within the framework of a business transaction (max. three months over one year)

- Diplomats and consular officials, as well as their families and staff

- Fitters or technical instructors in connection with urgent installation or repair of machinery ( $\max$. two months.)

- Temporary radio or television broadcast by Sveriges Radio AB, Sveriges Television AB, Sveriges Utbildningsradio AB or Nordisk Television AB (max. one month)

- Performers, technicians and other tour staff, provided that the performer has been invited by an established arranger ( $\max .14$ days over one year)

- $\quad$ Professional athletes and functionaries who participate in international competitions ( $\max .3$ months over one year)

- Railway personnel and lorry drivers in international commercial traffic

- Drivers and staff of tourist buses (max. 3 months)

- Representatives who work temporarily as salespeople, journalists, etc., for a company that does not have a branch or office in Sweden

- Caregivers employed for a person who is visiting Sweden (max. 3 months over one year)

- Visiting research fellows or teachers at higher education institutions who participate in research, teaching or lecturing activities (max. 3 months over one year)

- People who live and work in, but are not citizens of, an EU/EEA country or Switzerland and who want to work in Sweden temporarily as a contractor or the equivalent

- Representative commitment by management level

- Contract and Service Agreement negotiations

- Business meetings (such as a one time or regular business meeting for strategy or coordination for example)

- Visits in preparation of an upcoming assignment

- Meetings regarding the requirement process for a project

- Supervision (monitoring project progress)

- Passive participation at conferences and events 


\section{International Reference for Defining "Business Activities"}

As reflected in the assessment above, the distinction between 'business activity' and 'work' is exceedingly ambiguous. Consequently, companies do not have clear directions when sending their employees for short-term assignments, whether a work permit and visa is required or if the worker can enter on business (Note 2). To avoid possible sanctions for non-compliance with local immigration rules, labour laws and tax regulations, it is critical to identify the nature of the activities that can be legitimately carried out on "business" during short-term assignments or, on the contrary, activities which require a work permit.

In the absence of clear definitions, both in the Schengen visa rules and in Member State legislation, we outline below several EU and international regulations and relevant documents which could be considered for the purpose of defining business activities. Business activities are closely interconnected with the definition of employment (Note 3) and we have therefore extended our research on both the criteria for defining "business" (when available) and, on the contrary, under which conditions the relationship can be considered an "employment relationship". Below is an overview of some international standards and regulations that could be taken into consideration.

\subsection{European Union Legislation}

It is important to note that individual member state case-law regarding the concept of a "worker" does not take precedence over EU legal decisions and frameworks. That concept must be defined in accordance with objective criteria which distinguish the employment relationship by reference to the rights and duties of the persons concerned. The essential feature of an employment relationship (note 4) is that, for a certain period of time, a person performs services for and under the direction of another person, in return for which he receives remuneration (note 5). If we can identify criteria for defining "worker" and "employment relationship", a few references can be found to the definition of business activity and/or business visitors.

Art. 1, para 3(a) and 3(b) of the Posted Worker Directive(note 6) set forth that the Directive shall apply under certain circumstance but always provided there is an employment relationship between the employer and the worker during the period of posting. The Directive, however, does not define who must be considered the "employer", while indicates (art. 2, para 2) that the definition of a worker is that which applies in the law of the Member State to whose territory the worker is posted" (Note 7), thus not providing any useful guidance.

The Practical Guide issued by the European Commission identified useful criteria (Note 8) in the area of workers posted within the EU, to determine when a direct relationship exists between the sending company (formal employer) and the posted worker. Criteria governing when a direct relationship exists between the employer (i.e. sending company) and the worker, include the following: (i) responsibility for recruitment; (ii) it must be evident that the contract was and still is applicable throughout the posting period to the parties involved in drawing it up and stems from the negotiations that led to recruitment; (iii) the power to terminate the contract of employment (dismissal) must remain exclusively with the sending company; (iv) the sending company must retain the power to determine the "nature" of the work performed by the posted worker, not in terms of defining the details of the type of work to be performed and the way it is to be performed, but in the more general terms of determining the end product of that work or the basic service to be provided; (v) the obligation with regard to the remuneration of the worker rests with the undertaking which concluded the employment contract. This is without prejudice to any possible agreements between the employer in the posting State and the undertaking in the State of employment on the manner by which the actual payments are made to the employee; (vi) the power to impose disciplinary action on the employee remains with the sending company.

It is worth noting that, Point 7 of the recitals of Directive 2009/52 (Note 9) outlines that "the definition of employment should encompass its constituent elements, namely activities that are or ought to be remunerated, undertaken for or under the direction and/or supervision of an employer, irrespective of the legal relationship".

A general and non-exhaustive definition of "business activity" can be found in the proposal (Note 10) for revision of the Blue Card Directive (Directive 2009/50). Business activity is defined as "a temporary activity related to the business interests of the employer, such as attending internal and external business meetings, attending conferences and seminars, negotiating business deals, undertaking sales or marketing activities, performing internal or client audits, exploring business opportunities, or attending and receiving training".

The European Commission (Note 11) consulted the European Economic and Social Committee (EESC) regarding the negotiations on Mode 4 GATS (movement of physical persons) (Note 12). The EESC divided Mode 4 service suppliers into three broad categories: (a) Intra-corporate Transfers, (b) Business Visitors and (c) Contractual Service Suppliers, and defined business visitors (Note 13)-quite restrictively-as: "a representative of a foreign services 
supplier who temporarily enters the EU for one of the following purposes: (a) to negotiate the sale of services; $(b)$ to conclude contracts to sell services; or (c) to set up an establishment (subsidiary, branch or office)". EESC points out that "business visitors must not themselves supply services in the EU" and requests WTO to specify that transfers shall not exceed 90 days (Note 14).

\subsection{OECD Tax Model Convention}

Section 8.14 of the Commentary (http://www.oecd.org/berlin/publikationen/43324465.pdf) to Art. 15 of the new OECD Tax Model Convention (OECD Model tax convention on income and capital, 2014) (which set forth the rules for the international taxation of income from employment) indicates that the following additional factors may be relevant to determine the existence of an employment relationship, in order to identify the actual employer: (i) who has the authority to instruct the individual regarding the manner in which the work has to be performed; (ii) who controls and has responsibility for the place at which the work is performed; (iii) the remuneration of the individual is directly charged by the formal employer to the enterprise to which the services are provide); (iv) who puts the tools and materials necessary for the work at the individual's disposal; (v) who determines the number and qualifications of the individuals performing the work; (vi) who has the right to select the individual who will perform the work and to terminate the contractual arrangements entered into with that individual for that purpose; (vii) who has the right to impose disciplinary sanctions related to the work of that individual; (viii) who determines the holidays and work schedule of that individual"?

\subsection{International Labour Organization (ILO) Standards}

The Employment Relationship Recommendation, No. 198, issued by the International Labour Organization (ILO), on June 16, 2006, set forth specific indicators of the existence of an employment relationship. Those indicators might include: A) the fact that the work: (i) is carried out according to the instructions and under the control of another party; (ii) involves the integration of the worker in the organization of the enterprise; (iii) is performed solely or mainly for the benefit of another person; (iv) must be carried out personally by the worker; $(v)$ is carried out within specific working hours or at a workplace specified or agreed by the party requesting the work; (vi) is of a particular duration and has a certain continuity; requires the worker's availability; or involves the provision of tools, materials and machinery by the party requesting the work; $B$ ) periodic payment of remuneration to the worker: (i) the fact that such remuneration constitutes the worker's sole or principal source of income; (ii) provision of payment in kind, such as food, lodging or transport; recognition of entitlements such as weekly rest and annual holidays; (iv) payment by the party requesting the work for travel undertaken by the worker in order to carry out the work; or $(v)$ absence of financial risk for the worker.

\section{OECD Income Tax Analysis}

The income tax analysis that arises from short-term assignments has two major, but distinct, issue areas: (1) permanent establishment and (2) payroll. That is, there can be permanent establishment issues without payroll tax issues; payroll tax issues without permanent establishment issues; or both. Both issue areas are discussed below in the context of the new OECD Model Tax Convention. (OECD Model Tax Convention on Income and on Capital, 2017)

Permanent Establishment. It is a general principle of international taxation that a business enterprise that is not resident in a country will be taxed on profits attributable to a permanent establishment in another country. (OECD Model Tax Convention)In the context of the short-term assignments, there are two principal ways by which a permanent establishment can be triggered where one beforehand did not exist. The first way is when the worker, as a dependent agent of the enterprise, (a) habitually concludes contracts in the country of assignment on behalf of the enterprise, or (b) habitually plays the principal role in the conclusion of contracts without material modification by the enterprise. ( OECD Model Tax Convention)It is relatively straightforward to prevent the former from occurring, as the business visitor can be barred by the enterprise from executing contracts while on the short-term assignment. Additionally, many tax conventions only provide that a permanent establishment is triggered from the habitual conclusion of contracts by a dependent agent of the enterprise. That is, such conventions do not provide for a permanent establishment to be formed when the dependent agent habitually plays the principal role in the conclusion of contracts. (2006 U.S. Model Tax Convention)

The enterprise that effectively and prospectively monitors its short-term assignees will have documented policies and procedures in place for activities that can and cannot be performed in the countries of assignment, in the context of contract negotiation. However, such policies and procedures need to be enforced on the assignee; otherwise, they will be meaningless in preventing the occurrence of a permanent establishment. Further, the employment contracts of 
such assignees can have provisions that provide the actions of such assignees that trigger a permanent establishment for the enterprise, without prior express written approval of the enterprise, will be void ab initio.

The second principal way by which a permanent establishment can be triggered by the use of short-term assignments is through an installation project that lasts more than twelve months. Such a project can trigger a permanent establishment. (OECD Model Tax Convention) As stated above, many countries, such as Germany, allow for short-term assignments for installation projects, but often not for the length of twelve months. It is when short-term assignments are used on a rotational basis that can cause an installation project to last more than twelve months and thus inadvertently trigger the permanent establishment. The way such a permanent establishment is prevented is by the enterprise's maintenance and enforcement of strong policies and procedures to ensure that installation projects have firm completion dates safely in advance of twelve months, and if necessary, divide such projects to ensure that a permanent establishment is not created.

\subsection{Payroll}

A short-term assignment will not create income tax liability issues for the affected assignee on any compensation allocable to the assignment provided that three rules are all satisfied under Article 15 of the OECD Model Tax Convention (which sets forth the rules for taxation of income of employment for an individual who is tax resident in one country and performing personal services in another country): (OECD Model Tax Convention)

a. The assignee must be present in the country of assignment for not more than 183 days in any 12-month period beginning or ending in the relevant fiscal year. The underlined language makes this not a 183-day rule, but rather a 91-day rule, as it prevents the assignee, for example, from being in the country of assignment for the last five months of the fiscal year and the first five months of the next fiscal year.

b. The compensation must be paid by, or on behalf of, an employer that is not be tax resident in the country of assignment. There is strong focus here on who actually is the employer, to prevent the use of a "nominal employer" outside the country of assignment. If the employer is tax resident in the country of assignment, then the compensation allocable to the assignment will be taxable to the assignee, regardless of the length of the stay under the assignment. As a result, the aforementioned factors, under Section 8.14 of the OECD Commentary to Article 15 of the OECD Model Tax Convention, that may be relevant to determine the existence of an employment relationship, in order to identify the actual employer, should be utilized to determine (i) whether the actual employer is tax resident in the country of assignment, and (ii) if so, the extent to which the assignee is taxable on compensation allocable to the assignment.

c. The compensation allocable to the assignee must not be borne by a permanent establishment that the assignee's employer has in the country of assignment. In this situation, a multinational employer needs to ensure that its payroll function clearly communicates to its internal accounting function that an intercompany chargeback or allocation cannot occur without the result of creating taxable compensation to the affected employee.

\section{Conclusions}

We have undertaken an exhaustive comparison of the various definitions of business and employment to identify common criteria in the assessment of the legitimacy of business visitors' activities (BVs). In our opinion, the most important criteria to qualify an activity as business are the following: (i) BVs must be formally employed by the sending company; (ii) Sending company must retain authority to instruct BVs, to impose disciplinary sanctions, to determine holidays, work schedule and to terminate employment relationship; (iii) Activities to be carried out by BVs must be carried out for the interest of the sending company; (iv) BVs must be remunerated by the sending company; (v) Sending company must pay all travel costs; (vi) BVs cannot be integrated in the host company's organization the services provided must be an integral part of the business activities of the sending company ; (vii) according to Schengen Visa Code, BVs' stay cannot exceed 90 days (this include stays in all Schengen countries) in any 180 days period; (viii) The sending company must maintain and enforce strong policies and procedures to ensure that BV's activities, either solely or in conjunction with other BVs, do not trigger inadvertent permanent establishments in the countries of assignment; and (ix) The sending company properly monitors the length, the employment relationship and the internal accounting relating to short-term assignments, in order to avoid inadvertent taxation of BV's compensation allocable to the assignment. 


\section{Acknowledgements}

We extend our gratitude to our international partners who provided country contributions: Elmar Drabek (Austria), Bernard Caris (Belgium), Tommy Angermair (Denmark), Karl Waheed (France), Bettina Offer (Germany), Kalypso Kontogianni (Greece), Marcel Reurs (Holland), David Kiss (Hungary), Tane Feldman (Luxembourg), Jean Philippe Chetcuti (Malta), Anca Vatasoiu (Romania), Ana Garicano (Spain), Jonas Lindblad (Sweden), Karolina Schiffter (Poland), Ana Pedro de Castro (Portugal), Nina Perch Nielsen (Switzerland). We also thank Kristin Melia for her editorial assistance.

\section{References}

2006 U.S. Model Tax Convention, Art. 5, para. 5.

Commission Implementing Decision. (2011). 5501 Final of 4 August 2011.

Council Decision 1999/436/EC of 20 May 1999.

OECD Model tax convention on income and capital. (2014).

OECD Model Tax Convention on Income and on Capital. (2017).

OECD Model Tax Convention, Art. 15, para. 2.

OECD Model Tax Convention, Art. 5, para. 3.

OECD Model Tax Convention, Art. 5, para. 5.

OECD Model Tax Convention, Art. 7, para. 1.

Retrieved from http://www.oecd.org/berlin/publikationen/43324465.pdf

\section{Notes}

Note 1 . The table is a concise legal summary and should not be read as a comprehensive legal opinion

Note 2. Only citizens from countries which have a visa waiver program with the EU can enter the Schengen area without a visa, while any other citizens will require a specific business visa

Note 3. As noted in the Commentary to art. 15 of OECD Tax Model Convention (Sections 8.5 and 8.6) in some cases, services rendered by an individual to an enterprise may be considered to be employment services even though these services are provided under a formal contract for services between the host company and the enterprise by which the individual is formally employed. In such cases, the relevant domestic law may ignore the way in which the services are characterised in the formal contracts. It may prefer to focus primarily on the nature of the services rendered by the individual and their integration into the business carried on by the enterprise that acquires the services to conclude that there is an employment relationship between the individual and that enterprise.

Note 4. For an overview of the criteria used by different EU members in determining the existence of an employment relationship, see REGULATING THE EMPLOYMENT RELATIONSHIP IN EUROPE: A guide to Recommendation No. 198, by ILO and ELLN, March 2013, pag. 28 to 51

Note 5. (see, in particular, Case 66/85 Lawrie-Blum [1986] ECR 2121, paragraphs 16 and 17; Case C-176/96 Lehtonen and Castors Braine [2000] ECR I-2681, paragraph 45; Case C-138/02 Collins [2004] ECR I-2703, paragraph 26; Case C-456/02 Trojani [2004] ECR I-7573, paragraph 15; and Case C-392/05 Alevizos [2007] ECR I-0000, paragraph 67), quoted in An Autonomous EU definition of "Worker" - Pitfalls and Opportunities for the European Labour Movement' - Nicola Countouris (UCL Laws), 2015

Note 6. DIRECTIVE 96/71/EC OF THE EUROPEAN PARLIAMENT AND OF THE COUNCIL of 16 December 1996 concerning the posting of workers in the framework of the provision of services

Note 7. Countouris, cit. - According to the author: "Traditionally, the letter of EU social law has either shied away from defining the personal scope of application of its provisions, or has expressly reserved that task to rules developed in the national legal order. A number of Treaty provisions refer to or use the term 'worker', but without offering any explicit indication in respect of its meaning. Other provisions appear to reserve the role of defining terms such as 'employee' or 'contract of employment or employment relationship' exclusively to national law."

Note 8. Practical guide - The Legislation that applies to workers in the European Union (EU), the European Economic Area (EEA) and in Switzerland, pag. 8-European Commission 2012 
Note 9. DIRECTIVE 2009/52/EC of THE EUROPEAN PARLIAMENT AND OF THE COUNCIL of 18 June 2009, providing for minimum standards on sanctions and measures against employers of illegally staying third-country nationals - Art. 2 of Directive defines 'employment' as the exercise of activities covering whatever form of labour or work regulated under national law or in accordance with established practice for or under the direction and/or supervision of an employer; and 'employer' as any natural person or any legal entity, including temporary work agencies, for or under the direction and/or supervision of whom the employment is undertaken.

Note 10. 2016/0176 (COD)

Note 11. Opinion of the European Economic and Social Committee (EESC) on the General agreement on trade in services (GATS) - Mode 4 negotiations (movement of physical persons), 286/28 in Official Journal of the EU, 17.11.2005

Note 12. GATS Mode 4 is defined as the supply of a service by a supplier of one WTO member through the presence of natural persons in the territory of another WTO member on a temporary basis. EESC outlines that GATS Mode 4 covers a very particular form of movement of persons. It has three essential features: 1) it is temporary; 2) it is decided and its purpose is controlled by the service supplier; 3 ) it neither defines nor protects the rights of the employees concerned, which may be regulated by any State of destination

Note 13. EESC Opinion, point 2.4

Note 14. EESC Opinion, point 2.5.1, para 2 